nąć na jego innowacyjność, a w efekcie pozwolić na wzrost satysfakcji turystów, wyższy poziom zysku z działalności gospodarczej podmiotów, zwiększenie udziału w rynku, kreację nowego wizerunku, wzrost atrakcyjności oferty turystycznej. Mając powyższe na uwadze prognozuję dalszy dynamiczny rozwój turystyki sportowej.

\title{
Bibliografia
}

GAMMON S., ROBINSON T., 1997, Sport and Tourism: A conceptual Framework, „Journal of Sport Tourism”, Oxford, 4, (3), s. 21-26. HADZIK A., 2014, Turystyka sportowa ze szczególnym uwzględnieniem międzynarodowych widowisk sportowych, Wyd. Akademii Wychowania Fizycznego w Katowicach, Katowice.

KAZIMIERCZAK M., MALCHROWICZ-MOŚKO E., 2013, Turystyka sportowa - specyfika i trendy rozwojowe, „Folia Turistica”, 28.

Ross D., 2001, Developing Sports Tourism. An eGuide for Destination Marketers and sports Events Planners, National Laboratory for Tourism and eCommerce, University of Ilinois at Urbana Champaign, http://www.lib.teiher.gr/webnotes/sdo/Sport \%20Tourism/Sport-Tourism\%20Development\%20Guide.pdf.

STANDEVEN J., DEKNOP P., 1999, Sport Tourism, Human Kinetics, Champaign, Illinois.

\author{
Agnieszka Niezgoda \\ Uniwersytet Ekonomiczny w Poznaniu \\ Katedra Turystyki
}

\section{TURYSTYKA SPORTOWA - GŁOS W DYSKUSJI}

Termin "turystyka sportowa” można zastosować do formy turystyki wyodrębnionej na podstawie kryterium motywacji podróży. Dotyczy zatem zachowania konsumentów, którzy uwzględniają sport jako motyw wyjazdu turystycznego. Takie podejście nie różnicuje, czy turystyka sportowa ma dotyczyć wyjazdów poświęconych uprawianiu sportu czy wyjazdów w celu udziału w widowiskach sportowych (podejście takie prezentuje V.C. Middleton). Analogicznie rozpatrywana bywa turystyka kulturowa, która jest uprawiana być może zarówno przez tych, którzy biorą udział w widowiskach kulturalnych, jak też przez tych, którzy korzystają w jakikolwiek sposób z dóbr kultury.

Przyjmując kryterium motywacji należy podkreślić, że nie jest to kryterium ostre i podstawowym założeniem jest fakt, że turysta podejmuje podróż turystyczną z uwagi na więcej niż jeden motyw. Zatem uprawiając "turystykę sportową" może brać pod uwagę również wypoczynek, krajoznawstwo czy inne motywy.

Uwzględnienie różnych motywów związanych ze sportem pozwala na podział turystyki sportowej ze względu na ujęcie węższe (wyjazd w celu udziału w imprezach sportowych) oraz ujęcie szersze (wyjazd w celu uprawiania sportu). Konieczność występowania infrastruktury dla turystów uprawiających turystykę sportową oraz konieczność predyspozycji i umiejętności wymaganych do uprawiania tej formy turystyki wynika z tego, jaki jest cel wyjazdu i jakie ujęcie - szerokie czy wąskie.

Przyszłość turystyki sportowej związana jest z perspektywami dotyczącymi zachowania turystów, bo to oni i ich preferencje będą kształtować popyt turystyczny, a zgodnie z marketingowym ujęciem - również podaż turystyczną. Obserwuje się trend „zdrowego i aktywnego życia” oraz modę na aktywność fizyczną, szczególnie wśród zamożnej grupy społeczeństwa, mieszkańców miast i tzw. bogatych przedmieść. Można sądzić, że przełoży się to na wzrost zainteresowania turystyką sportową.

http://dx.doi.org/10.18778/0867-5856.26.1.16

\author{
Anna Pawlikowska-Piechotka \\ Akademia Wychowania Fizycznego w Warszawie \\ Wydział Turystyki i Rekreacji \\ Politechnika Warszawska \\ Wydział Architektury
}

\section{TURYSTYKA SPORTOWA - CZYNNE I BIERNE UCZESTNICZENIE W WYDARZENIACH SPORTOWYCH (AMATORZY I ZAWODOWCY)}

Turystyka sportowa - ten termin w literaturze przedmiotu jeszcze niedawno nie pojawiał się w pracach naukowych na temat turyzmu (COOPER i in. 2005, GOŁEMBSKI, red. 2002, KUREK, red. 2007), a przecież samo zjawisko nie jest nowe. Tradycja uczestnictwa aktywnego lub pasywnego w wydarzeniach sportowych poza miejscem stałego zamieszkania ma już w warunkach europejskich prawie 3000 lat (licząc chociażby od podróży podejmowanych w celu udziału biernego lub czynnego w antycznych greckich igrzyskach olimpijskich w VIII w. p.n.e.). Zatem tu- 
rystyka sportowa istniała od dawna, ale ta forma nie była ani wyróżniona, ani nazwana. Jest od końca XX w. coraz bardziej wyrazista (w skali globalnej) na tle innych form turystyki, w wyniku zwiększającej się mobilności współczesnego społeczeństwa, coraz większej liczby atrakcyjnych imprez sportowych, a także ich energicznej promocji na co zwracają uwagę badacze przedmiotu (GAMMON, ROBINSON 2003, LOMINE, EDUMUNDS 2007, RITCHIE, ADAIR, red. 2004). Biorąc pod uwagę specyficzny charakter coraz bardziej popularnej formy turystyki, jaką jest turystyka sportowa, możemy wyodrębnić w dwóch grupach (uczestnictwo bierne i czynne) kilka jej wątków:

1. Podróże w celu biernego uczestnictwa w wydarzeniach sportowych:

- Turystyka sportowa masowa twarda (zorganizowane grupy kibiców) lub miękka (wyjazdy indywidualne) - podróż podejmowana w celu uczestniczenia jako widz w meczu piłkarskim lub innym sportowym wydarzeniu (także całej serii zawodów: igrzyska olimpijskie, mistrzostwa świata). Nie jest nowym zjawiskiem, takie podróże miały miejsce już w antycznej Grecji (LIPOŃSKI 2012).

- Turystyka sportowa nostalgiczna - poznawcze podróże podejmowane w celu odwiedzenia miejsc związanych z wielkimi wydarzeniami sportowymi i gwiazdami sportu. Turyści są zainteresowani zarówno obiektami historycznymi (antyczne stadiony w Olimpii, Delfach, Atenach, Efezie), jak i współczesnymi monumentalnymi obiektami sportowymi, a szczególnie siedzibami sławnych klubów (stadion Manchester United, FC Barcelona, Real Madryt). Chętnie odwiedzane są obiekty - ikony ważnych wydarzeń sportowych (Zespół Olimpijski w Pekinie, najnowsze obiekty olimpijskie w Londynie, Stadion Narodowy w Warszawie, korty Wimbledon pod Londynem). Niektóre z nich są niezwykle popularne i odwiedzane przez setki tysięcy turystów w skali roku.

2. Podróże w celu aktywnego uczestnictwa w wydarzeniach sportowych:

- Aktywna turystyka sportowa dotyczy tych, którzy podróżują, aby aktywnie uprawiać daną dyscyplinę sportu. W tym zbiorze turystów są zarówno profesjonalni sportowcy wyczynowi, dla których jest to sposób zarobkowania ${ }^{1}$, jak i amatorzy łaknący sportowych przeżyć, ale traktujący wysiłek fizyczny także w kategoriach wypoczynku i rozrywki, w tym w celu zaspokajania próżności i snobizmu. Osoby te są często gotowe płacić krocie za wpisowe i możliwość startu w prestiżowych zawodach, zagranie meczu tenisowego lub golfowego na słynnym korcie lub polu golfowym, za zaszczyt brania udziału w słynnych regatach, za naukę danej dyscypliny sportu u wielkich mistrzów, za uczestniczenie w płatnych kursach doszkalających mamy zatem $w$ tym przypadku również element turystyki edukacyjnej i kwalifikowanej (GAMMON, ROBINSON 2003, LOMINE, EDUMUNDS 2007, RITCHIE, ADAIR, red. 2004, THEOBALD 2005, UN WTO 2003).

- Sportowa turystyka przygodowa łączy się z podróżami po trudno dostępnych terenach, poza utartymi szlakami; jest oparta na tradycji wypraw w nieznane i tęsknocie za ekscytującymi odkryciami geograficznymi pełnymi trudów i zaskakujących sytuacji. We współczesnych czasach łączy się z takimi dyscyplinami, jak wspinaczka wysokogórska, hiking, samotne żeglarstwo. Rywalizacja sportowa polega w tym przypadku na kompletowaniu „,korony gór”, zdobywaniu trudnego szczytu nową trasą lub w czasie ekstremalnych warunków, biciu rekordów czasu w pokonywaniu trudnego szlaku żeglarskiego. Często zazębiona z doom tourism. Nie jest to nowa forma turystyki, wymienione dyscypliny rywalizacji są od dawna obecne w kulturze europejskiej. Należy zaznaczyć, że wiele spośród różnych rodzajów aktywności podejmowanej w ramach sportowej turystyki przygodowej jest tradycyjnie przypisywanych turystyce kwalifikowanej (LIPOŃSKI 2001, 2012).

Odpowiedzi kolejno na postawione w ankiecie Redakcji czasopisma „Turyzm/Tourism” pytania:

1. Turystyka sportowa (we wszystkich jej odmianach) istnieje już kilka tysięcy lat, ale rozwija się szczególnie dynamicznie od końca XX w. Zdaniem jej organizatorów ma przed sobą obiecującą przyszłość, a już obecnie generuje znaczące dochody i ma pozytywny wpływ na ożywienie gospodarcze, niesie także istotne pozaekonomiczne korzyści - o czym przekonaliśmy się w Polsce w czasie mistrzostw Euro 2012 (RITCHIE, ADAIR, red. 2004, UNWTO 2003).

2. Turystyka sportowa (we wszystkich odmianach) mieści się w zakresie obowiązujących obecnie definicji turystyki, przede wszystkim sformułowanych przez UN WTO, pod warunkiem podejmowania podróży ze stałego miejsca zamieszkania oraz przynajmniej jednego noclegu podczas wyjazdu (COOPER i in. 2005, GOŁEMBSKI, red. 2002, KUREK, red. 2007, UNWTO 2012). W definicji terminu "sport" mieszczą się tylko aktywne jej formy i niektóre formy turystyki kwalifikowanej (te, gdzie mamy do czynienia z elementami rywalizacji sportowej) (LIPOŃSKI 2001, UNWTO 2003).

3. Aby uprawiać turystykę sportową bierną (w formie twardej, miękkiej lub nostalgicznej) nie są wymagane żadne predyspozycje ani szczególne umiejętności, poza fascynacją sportem i zainteresowaniem wydarzeniami sportowymi, ciekawością świata. Turyści ci korzystają z infrastruktury przygotowanej dla zwykłych gości (baza noclegowa, gastronomiczna, transportowa oraz towarzysząca).

${ }^{1}$ Jak się wydaje, sportowcy profesjonalni w czasie wyjazdów na zawody sportowe czy zgrupowania, powinni być konsekwentnie kwalifikowani do zbioru 'turystów' (przez analogię do turystyki biznesowej i podróży służbowych - zgodnie z kryteriami opracowanymi przez UN WTO). 
4. Aby uprawiać aktywnie turystykę sportową należy mieć dokładnie takie predyspozycje, kwalifikacje i specjalistyczny sprzęt, jaki jest dla danej dyscypliny sportu niezbędny. Inne będą wymagania dla sportów wodnych (żeglarstwo, wioślarstwo, windsurfing), dla sportów zimowych (snowbboard, narciarstwo, łyżwiarstwo), dla wspinaczki wysokogórskiej, a inne dla gry w golfa. Naturalnie część infrastruktury turystycznej podstawowej (baza noclegowa, gastronomiczna, transport, elementy bazy komplementarnej) pozostaje niezmienna, potrzebna turystom bez względu na uprawianą dyscyplinę sportową i rodzaj uczestnictwa.

5. Tradycyjnie sezonowość uprawiania wielu dyscyplin sportu łączyła się z konkretnymi wymaganiami topograficznymi i klimatycznymi. Obecnie mamy do czynienia z technologiami pozwalającymi na całoroczne uprawianie wielu dyscyplin sportu, niegdyś ściśle związanych z sezonowością i regionalizacją (LIPOŃSKI 2012). Oczywiście nic nie zastąpi romantyzmu w warunków naturalnych.

6. Wydaje się, że dla ułatwienia planowania badań nad turystyką sportową, osiągnięcia przejrzystej jej kategoryzacji i parametryzacji należy rozróżnić następujące segmenty problemowe: a) turystykę sportową bierną i czynną, b) podróż, której głównym celem jest uprawianie sportu, a nie inne przyczyny i motywy, c) podział na uczestniczących w turystyce sportowej zawodowców oraz amatorów (GAMMON, ROBINSON 2003, LOMINE, EDUMUNDS 2007, RITCHIE, ADAIR, red. 2004, UNWTO 2003).

Należy podkreślić, że turystyka sportowa (tak jak i inne formy turystyki) rzadko występuje w formie „czystej”. Można przypuszczać, iż jej uczestnicy będą w czasie wyjazdu brać udział także w turystyce poznawczej (kulturowej, krajoznawczej, edukacyjnej), biznesowej czy wypoczynkowej. Dlatego podejmowane próby definicji, badania oraz mierzenie skali uczestnictwa metodami statystycznymi może okazać się dosyć skomplikowane, bowiem trudno jest czasem wyróżnić motyw główny podróży (KORSTANJE 2007, RITCHIE, ADAIR, red. 2004, THEOBALD 2005).

Na zakończenie uwaga natury ogólnej na temat potencjalnego niebezpieczeństwa, jakie może nieść dążenie za wszelką cenę do ścisłego definiowania i kategoryzacji pojęć, które ze swojej natury leżą na pograniczu różnych zjawisk. Jest to często niemożliwe i w przypadku turystyki sportowej w efekcie prowadzić do nadmiernego rozszerzania (lub zawężenia) tego terminu, zniekształcania tego pojęcia i odbiegania od popularnego znaczenia przydawanego intuicyjnie w języku codziennym przez społeczeństwo.

\title{
Bibliografia
}

COOPER Ch., Fletcher J., Fyall A., Gilbert D., WAnhill S., 2005, Tourism. Principles and Practice, Prentice Hall, Harlow.

GAMMON S., ROBINSON T., 2003, Sport and Tourism: A Conceptual Framework, „Journal of Sport \& Tourism”, 8 (1), s. 21-26, DOI: 10.1080/14775080306236; marzec 2016.

GOŁEMBSKI G. (red.), 2002, Kompendium wiedzy o turystyce, Wyd. Naukowe PWN, Warszawa.

KORSTANJE M., 2007, The Origin and Meaning of Tourism: Etymological Study, „Review of Tourism Research” (eRTR), 5 (5), s. 100108, www.academia.edu/353007; marzec 2016.

KUREK W. (red.), 2007, Turystyka, Wyd. Naukowe PWN, Warszawa.

LIPOŃSKI W., 2001, Humanistyczna encyklopedia sportu, Oficyna Wydawnicza Atena, Poznań.

LIPOŃSKI W., 2012, Historia sportu, Wyd. Naukowe PWN, Warszawa.

LOMINE L., EdUMUNDS J., 2007, Key Concepts in Tourism, Palgrave Key Concepts, Palgrave - Macmillan, London.

RITCHIE B.W., ADAIR D. (red.), 2004, Sport tourism. Interrelationships, impacts and issues, ser. „Aspects of Tourism”, Channel View Publications, Toronto.

THEOBALD W.F., 2005, The Meaning, Scope and Measurment of Travel and Tourism, [w:] Global Tourism, Elsevier, London, s. 1-6.

UNWTO, 2003, Sport and Tourism - Introductory Report (English version), UNWTO eLibrary, DOI: 10.18111/9789284404179; marzec 2016.

UNWTO, 2012, Compendium of Tourism Statistics. Glossary of tourism terms, UNWTO eLibrary, DOI: 10.18111/9789284414338; marzec 2016.

\author{
Alina Zajadacz \\ Uniwersytet im. A. Mickiewicza w Poznaniu \\ Wydział Nauk Geograficznych i Geologicznych \\ Katedra Turystyki i Rekreacji
}

\section{TURYSTYKA SPORTOWA - PRÓBA ZDEFINIOWANIA POJĘCIA}

Próba zdefiniowania pojęcia "turystyka sportowa" wymaga przypomnienia znaczenia podstawowych w tym przypadku terminów, takich jak „turystyka” oraz „sport”. Turystyka stanowi podzbiór podróży i jest definiowana jako „ogół czynności osób, które podróżują i przebywają w celach wypoczynkowych, służbowych lub innych nie dłużej niż przez rok bez przerwy poza swoim codziennym otoczeniem, z wyłączeniem wyjazdów, w których głównym celem jest działalność zarobkowa wynagradzana w odwiedzanej miejscowości (UNWTO 1991, za: KUREK, MIKA 2007, s. 12). Do podstawowych kryteriów identyfikacji wyjazdów turystycznych należy zatem: czasowa 